\title{
BAFICRINUS GEN. NOV. (CRINOIDEA, INADUNATA) FROM THE BOHEMIAN EARLY DEVONIAN (THE CZECH REPUBLIC)
}

\section{RUDOLF J. PROKOP}

\section{MARTINA NOHEJLOVÁ}

National Museum, Department of Palaeontology, Václavské náměstí, 11579 Praha 1, the Czech Republic; e-mails: rudolf.prokop@seznam.cz; martina_nohejlova@nm.cz

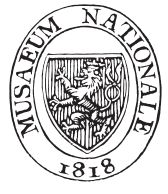

Prokop, R. J., Nohejlová, M. (2015): Baficrinus gen. nov. (Crinoidea, Inadunata) from the Bohemian Early Devonian (the Czech Republic). Acta Mus. Nat. Prague, Ser. B, Hist. Nat., 71(1-2): 25-30, Praha. ISSN 1804-6479.

Abstract. In washings of weathered Třebotov Limestone of Early Devonian, Late Emsian age, isolated radials and rarely, the almost complete calyxes of new zophocrinid crinoids, have been found. These crinoids are closely related to the genus Tiaracrinus and are described here as a new genus and new species, Baficrinus vigilis gen. nov. et sp. nov. A list of crinoid taxa and parataxa described from the Třebotov Limestone in the Barrandian Area is included herein.

Crinoidea, Inadunata, Zophocrinidae, Baficrinus gen. nov., Early Devonian, Emsian, Třebotov Limestone, Barrandian area, Bohemia.

Received November 13, 2015

Issued October, 2015

\section{Introduction}

Crinoid fossils from the washings of so called "white beds", are found in some abandoned and temporary exposures at different stratigraphic levels in the Barrandian area. They add fundamental contributions to our knowledge of Barrandian Devonian crinoids. This is also true of the Třebotov Limestone that was studied intensively during the 1980s and 1990s and has been regularly published (Prokop 1987, 1992). New information regarding Late Emsian crinoids from localities in Prague (1. Praha-Holyně, "V rokli" quarry, along the way to Slivenec; 2. Praha-Hlubočepy, abandoned quarry "U jezírka"; 3. Praha-Barrandov, road-cut) is discussed herein (Text-fig. 1). Extracted material from these washings continues to yield scientific information and continuing research is still in progress but slow paced because extracting fossils from washings is very timeconsuming. A related aspect presented in this paper is a summary of currently known taxa, and their occurrences in the above-named localities.

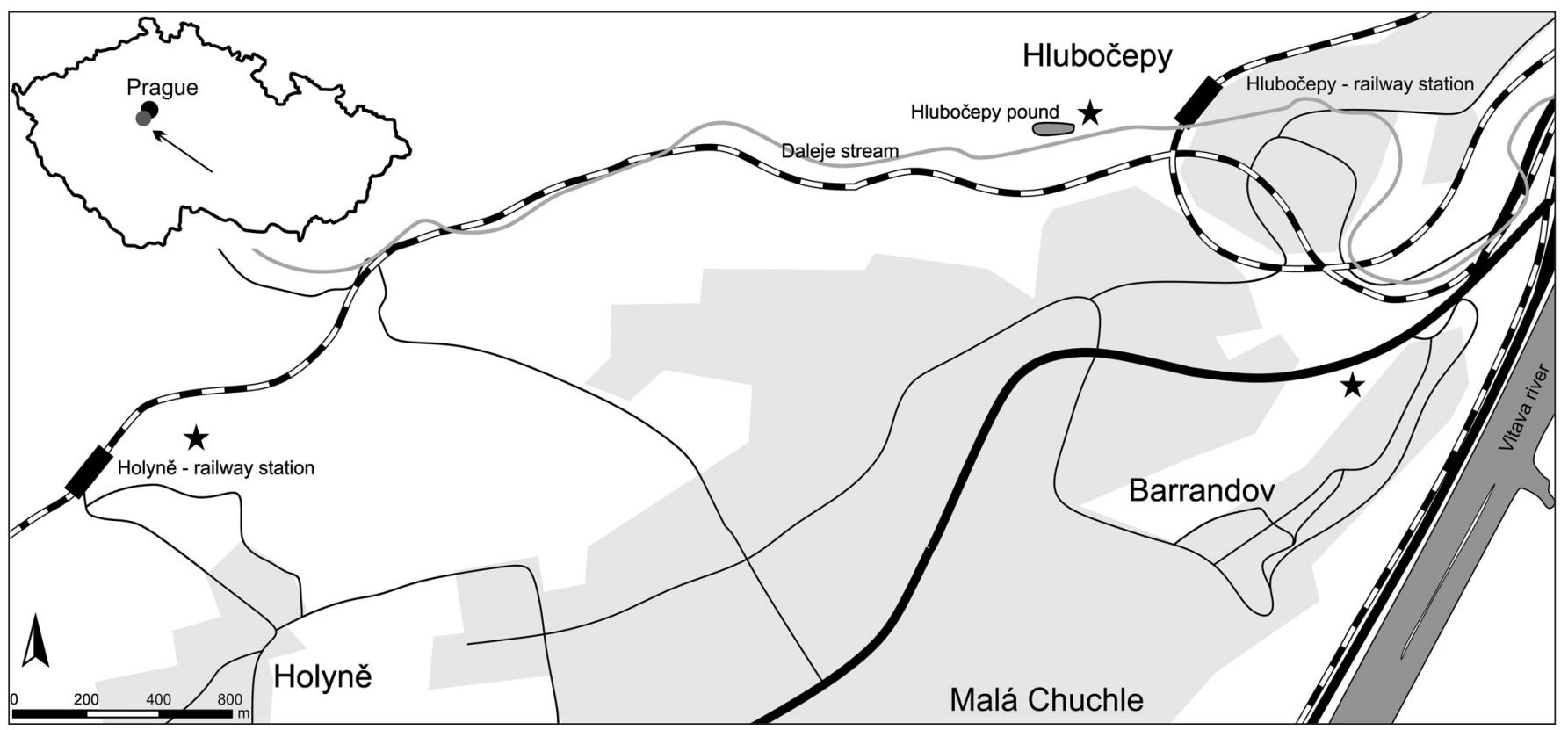

Text-fig. 1. Location of the localities Praha-Holyně, Praha-Barrandov and Praha-Hlubočepy (asterisk). 
During the systematic study of echinoderm assemblages from the Bohemian Devonian many isolated, morphologically prominent radial platelets and, fewer almost complete calyxes of an undescribed crinoid genus, have been recovered. They have been found in the washings of deeply weathered parts of the biomicritic Trrebotov Limestone (Late Emsian). The new crinoid is closely related the genus Tiaracrinus (abundant in Early Devonian of Bohemia), and described here as Baficrinus vigilis. gen. nov. et sp. nov.

\section{Systematic palaeontology}

\section{Subclass: Inadunata WACHSMUTH et SPRINGER, 1885 Order: Disparida Moore et LAUdon, 1943 \\ Family: Zophocrinidae S. A. MILleR, 1892}

Baficrinus gen. nov.

Type species: Baficrinus vigilis sp. nov., Early Devonian, Late Emsian (Dalejan), Bohemia.

D i a g n o s i s : Calyx minute, median globe to globular shaped (Ubaghs 1978, p. T99), widest at midheight, tapering abruptly to the tiny base which is composed of (probably) three low, poorly distinguished basals. Stem facet minute, smooth, tiny lumen not clearly visible. Calyx rounded square in oral or basal views, composed from four large, strongly vaulted, relatively massive radials. Sutures between the basal and radial platelets poorly developed. Tegmen and anal X unknown. Outer surface of the calyxinal platelets bear a complicated network of radial wrinkles in the central parts of radial plates and a similar network of convoluted transversal epispiral channels on their lateral parts. The arms (limbrachioids? after Haude 1993) unknown. In keeping with the straight, gently toothed upper margin of the radials; the tegmen was probably flat, similar to that of the crinoid genus Tiaracrinus (see Schultze 1867, Springer 1926, Moore et al. 1978, Le Menn 1990, Haude 1993).

\section{Baficrinus vigilis sp. nov.}

$$
\text { Pl. 1, Fig. 1-10 }
$$

Holotype: Isolated almost complete calyx NM-L42360, figured on P1. 1, Fig. 1a, $1 \mathrm{~b}$.

Paratype: Isolated almost complete calyx NM-L42361, figured on Pl. 1, Fig. 2a-2c.

Type horizon: Daleje-Třebotov Formation, Třebotov Limestone, Lower Devonian, Upper Emsian (Dalejan).

Type locality: Praha-Holyně, "V rokli" quarry, along the way to Slivenec

$\mathrm{M}$ a te ri a l. In addition to the type specimens there are more than 38 isolated radial platelets from washings of the weathered well-bedded, light-grey, micritic and biomicritic limestones of the uppermost part of the Trrebotov Limestone.

Des cription. See diagnosis of the genus.

Occurrence. Many specimens Baficrinus vigilis gen. et sp. nov. have been found in washings of weathered limestones from the type locality. Rarely, the isolated radials of these crinoids have been found in other localities of the
Třebotov Limestone: Praha-Hlubočepy, "U jezírka" quarry, and in the road-cut section of the Praha-Barrandov motorway.

R e m a rks: Baficrinus vigilis gen. et sp. nov. differs from the very similar crinoid genus Tiaracrinus by its minute, almost globular calyx with low and tiny base but primarily by the very complicated outer surface of radial platelets bearing deformed transversal epispires and various radial wrinkles. Plate boundaries are often poorly preserved.

\section{Crinoid taxa from the Třebotov Limestone}

A current list of crinoid genera from the washings of weathered parts of the well bedded light-grey micritic and biomicritic limestones of the Třebotov Limestone (Late Emsian) is included herein (Tab. 1, 2). This list complements older published reports (see Prokop 1987, 1992). The Třebotov Limestone was probably deposited in a quiet fairly deep neritic zone, with a disaerobic environment, and with only moderate current action. Transport of crinoid specimens to greater distances is not assumed - the limestones have yielded many crinoids in various growth stages (including very young minute specimens). These specimens include symbathocrinids, ramacrinids, calceocrinids, cyathocrinids and pygmaeocrinids.

All taxa presented here come from three significant localities of the Třebotov Limestone:

1. Praha-Holyně, "V rokli" quarry, along the way to Slivenec,

2. Praha-Hlubočepy, abandoned quarry "U jezírka",

3. Road-cut section on the Praha-Barrandov, motorway.

\section{Acknowledgements}

The authors are grateful to Jan Sklenář (National Museum, Prague) for graphic help, Vojtěch Turek (National Museum, Prague) for valuable comments of the manuscript and Ronald Parsley (Tulane University, New Orleans) for critical reading the manuscript and improving English. The research was supported by Ministry of Culture of the Czech Republic (DKRVO 2015/06, National Museum, 00023272).

\section{References}

Austin, T., Austin, T. Jr. (1843): Descriptions of several new Genera and Species of Crinoidea. - Annals and Magazine of Natural History, Ser. 1, 11(69): 195-207.

Bather, F. A. (1892): British fossil crinoids. - VII. Mastigocrinus loreus, nov. gen. et. sp., Wenlock Limestone, Dudley. - Annals and Magazine of Natural History, Ser. 6, 9(51): 194-202.

Bouška, J. (1947): Pygmaeocrinus, new crinoid from the Devonian of Bohemia. - Věstník Královské české společnosti nauk, Třída II (mathematicko-přírodovědecká), 1946: 1-4, 1 pl.

Bouška, J. (1948): Holynocrinus, new crinoid genus from the middle Devonian of Bohemia. - Journal of Paleontology, 22(4): 520-524.

Carpenter, P. H., Etheridge, R. Jr. (1881): Contributions to the study of the British Paleozoic crinoids. No. 1. On 
Table 1. Calyxes, cups and their isolated parts. All taxons presented here come from three significant localities of the Třebotov Limestone: 1. Praha-Holyně, "V rokli" quarry, along the way to Slivenec. 2. Praha-Hlubočepy, abandoned quarry "U jezírka". 3. Praha-Barrandov, section at the road-cut of the motorway. For situation of localities see Text-fig. 1.

\begin{tabular}{|c|c|c|c|}
\hline \multicolumn{4}{|c|}{ Calyxes and cups or their isolated parts } \\
\hline \multirow[b]{2}{*}{ Taxon } & \multicolumn{3}{|c|}{ Locality } \\
\hline & $\begin{array}{l}\text { Praha- } \\
\text { Holyně }\end{array}$ & $\begin{array}{c}\text { Praha- } \\
\text { Hlubočepy }\end{array}$ & $\begin{array}{c}\text { Praha- } \\
\text { Barrandov }\end{array}$ \\
\hline $\begin{array}{l}\text { Allagecrinus CARPEN- } \\
\text { TER et ETHERIDGE, } 1881\end{array}$ & + & & \\
\hline $\begin{array}{l}\text { Arthroacantha } \\
\text { WILLIAMS, } 1883 \\
\end{array}$ & + & + & \\
\hline $\begin{array}{l}\text { Aureocrinus PROKOP, } \\
1982\end{array}$ & + & & \\
\hline $\begin{array}{l}\text { Bactrocrinites SCHNUR, } \\
1849\end{array}$ & + & & \\
\hline $\begin{array}{l}\text { Briseocrinus PROKOP, } \\
1991\end{array}$ & + & & + \\
\hline $\begin{array}{l}\text { Catillocrinus SHUMARD, } \\
1865\end{array}$ & + & + & + \\
\hline Edriocrinus HALL, 1852 & + & + & + \\
\hline Elicrinus РROKOP, 1973 & + & + & + \\
\hline $\begin{array}{l}\text { Eohalysiocrinus } \\
\text { PROKOP, } 1970\end{array}$ & + & + & + \\
\hline $\begin{array}{l}\text { Gemmacrinus PROKOP } \\
\text { et PETR, } 1989\end{array}$ & + & + & \\
\hline $\begin{array}{l}\text { Hexacrinites Austin } \\
\text { et Austin, } 1843\end{array}$ & + & + & + \\
\hline $\begin{array}{l}\text { Holynocrinus BoUŠKA, } \\
1948\end{array}$ & + & & \\
\hline $\begin{array}{l}\text { Lecanocrinus HALL, } \\
1852\end{array}$ & + & + & + \\
\hline $\begin{array}{l}\text { Minicrinus PROKOP, } \\
1970\end{array}$ & + & + & + \\
\hline $\begin{array}{l}\text { Prokopicrinus FREST } \\
\text { et STRIMPLE, } 1977\end{array}$ & + & & \\
\hline $\begin{array}{l}\text { Pygmaeocrinus } \\
\text { BoUŠKA, } 1947\end{array}$ & + & + & + \\
\hline $\begin{array}{l}\text { Ramacrinus PROKOP, } \\
1969\end{array}$ & + & & + \\
\hline $\begin{array}{l}\text { Resetocrinus PROKOP } \\
\text { et PETR, } 1991\end{array}$ & + & + & + \\
\hline $\begin{array}{l}\text { Thalamocrinus MILLER } \\
\text { et GURLEY, } 1895\end{array}$ & & + & \\
\hline $\begin{array}{l}\text { Tiaracrinus SCHULTZE, } \\
1867\end{array}$ & + & + & + \\
\hline $\begin{array}{l}\text { Timocrinus PROKOP } \\
\text { et PETR, } 1994\end{array}$ & + & + & + \\
\hline $\begin{array}{l}\text { Treocrinus PROKOP } \\
\text { et PETR, } 1991\end{array}$ & + & + & + \\
\hline
\end{tabular}

Allagecrinus, the representative of the Carboniferous limestone series. - Annals and Magazine of Natural History, Ser. 5, 7(40): 281- 298.

Frest, T. J., Strimple, H. L. (1980): New diminutive camerate crinoids from the Ludlow of Oklahoma. - Geological Magazine, 117(03): 255-266.

Goldfuss, G. A. (1839): Beiträge zur Petrefactenkunde. Nova Acta Academiae Caesareae Leopoldino-Carolinae Naturae Curiosorum, 19(1): 329-364.

Goldring, W. (1923): Devonian crinoids of the State of New
Table 2. Columnals, pluricolumnals and other isolated skeletal ossicles from the same localities.

\begin{tabular}{|c|c|c|c|}
\hline \multicolumn{4}{|c|}{ Columnals, pluricolumnals and the other isolated skeletal ossicles } \\
\hline \multirow[b]{2}{*}{ Taxon } & \multicolumn{3}{|c|}{$\begin{array}{l}\text { Locality } \\
\end{array}$} \\
\hline & $\begin{array}{l}\text { Praha- } \\
\text { Holyně }\end{array}$ & $\begin{array}{c}\text { Praha- } \\
\text { Hlubočepy }\end{array}$ & $\begin{array}{c}\text { Praha- } \\
\text { Barrandov }\end{array}$ \\
\hline $\begin{array}{l}\text { Ammonocrinus } \\
\text { SPRINGER, } 1926\end{array}$ & + & + & + \\
\hline $\begin{array}{l}\text { Arachnocrins MEEK } \\
\text { et WORTHEN, } 1866 \\
\text { (AxAx) }\end{array}$ & + & + & + \\
\hline $\begin{array}{l}\text { Arthroacantha } \\
\text { WILLIAMS, } 1883\end{array}$ & & + & \\
\hline $\begin{array}{l}\text { Asperocrinus } \\
\text { STUKALINA, } 1975\end{array}$ & + & + & + \\
\hline $\begin{array}{l}\text { Aulnocrinus LEMENN, } \\
1970\end{array}$ & + & & \\
\hline $\begin{array}{l}\text { Cyclocharax MOORE } \\
\text { et JEFFORDS, } 1968\end{array}$ & + & & + \\
\hline $\begin{array}{l}\text { Cyclocion MOORE } \\
\text { et JEFFORDS, } 1968\end{array}$ & + & + & + \\
\hline $\begin{array}{l}\text { Cyclocrista MOORE } \\
\text { et JEFFORDS, } 1968\end{array}$ & & & + \\
\hline $\begin{array}{l}\text { Diamenocrinus } \\
\text { OEHLERT, } 1891\end{array}$ & + & & \\
\hline $\begin{array}{l}\text { Fabalium MOORE } \\
\text { et JEFFORDS, } 1968\end{array}$ & + & + & + \\
\hline $\begin{array}{l}\text { Floricyclus MOORE } \\
\text { et JEFFORDS, } 1968\end{array}$ & + & + & + \\
\hline $\begin{array}{l}\text { Gasterocoma } \\
\text { GoLDFuss, } 1839 \text { (BrBr) }\end{array}$ & + & + & + \\
\hline $\begin{array}{l}\text { Gilbertsocrinus } \\
\text { PHILLIPS, } 1836\end{array}$ & + & + & \\
\hline $\begin{array}{l}\text { Goniocion MOORE } \\
\text { et JeFFORDS, } 1968\end{array}$ & + & & \\
\hline $\begin{array}{l}\text { Hapalocrinus JAEKEL, } \\
1895 \text { (pinnulae) }\end{array}$ & + & & + \\
\hline $\begin{array}{l}\text { Holamptocrinus } \\
\text { PROKOP, } 2009\end{array}$ & + & + & + \\
\hline $\begin{array}{l}\text { Laudonomphalus } \\
\text { MoORE et JEFFORDS, } \\
1968\end{array}$ & + & + & + \\
\hline $\begin{array}{l}\text { Mastigocrinus BATHER, } \\
1892 \text { (plates of anal sac) }\end{array}$ & + & + & \\
\hline \begin{tabular}{l|} 
Mediocrinus \\
StUKALINA, 1965
\end{tabular} & + & + & + \\
\hline $\begin{array}{l}\text { Mooreanteris MILLER } \\
\text { in MOORE et JEFFORDS, } \\
1968\end{array}$ & + & & \\
\hline $\begin{array}{l}\text { Noctuicrinus } \\
\text { LEMENN, } 1985\end{array}$ & + & & + \\
\hline $\begin{array}{l}\text { Pandocrinus } \\
\text { STUKALINA, } 1965\end{array}$ & + & + & + \\
\hline $\begin{array}{l}\text { Parisocrinus } \\
\text { WACHSMUTH et } \\
\text { SPRINGER, } 1880\end{array}$ & + & + & + \\
\hline $\begin{array}{l}\text { Pentacauliscus MOORE } \\
\text { et JEFFORDS, } 1968\end{array}$ & + & + & \\
\hline $\begin{array}{l}\text { Pentamerostella MOORE } \\
\text { et JEFFORDS, } 1968\end{array}$ & + & + & \\
\hline $\begin{array}{l}\text { Platyparalellus MOORE } \\
\text { et JEFFORDS, } 1968\end{array}$ & & + & \\
\hline $\begin{array}{l}\text { Platystela MOORE et } \\
\text { JEFFORDS, } 1968\end{array}$ & + & + & + \\
\hline $\begin{array}{l}\text { Pterinocrinus } \\
\text { GoLDRING, } 1923\end{array}$ & + & + & + \\
\hline $\begin{array}{l}\text { Simakocrinus } \\
\text { PROKOP, } 2013\end{array}$ & + & + & + \\
\hline
\end{tabular}


York. - Memoir, New York State Museum, 16: 1-160, pl. $1-60$.

Hall, J. (1852): Palaeontology of New-York, vol. II: Containing descriptions of the organic remains of the lower middle division of the New-York System (equivalent in part to the Middle Silurian rocks of Europe). - Geological Survey of New-York (C. van Benthuysen printer), Albany, 362 pp. +85 pls.

Haude, R. (1993): Limbrachoide, ungewöhnliche Arme der bisher "armlosen" exotische Seelilie Tiaracrinus (Devon, Rheinisches Schiefergebirge). - Göttinger Arbeiten zur Geologie und Paläontologie, 58: 87-96.

Jaekel, O. M. (1895): Beiträge zur Kenntniss der palaeozoischen Crinoiden Deutschlands. - Palaeontologischen Abhandlungen, Neue Folge, 3: 1-116, pl. 1-10.

Le Menn, J. (1970): Les crinoïdes du Sieginien supérieur da la rade de Brest (Finistère); These de Docteur. - MS, Faculté des Sciences de l'Université de Rennes, 107 pp.

Le Menn, J. (1985): Les Crinoïdes du Dévonien inférieur et moyen du Massif armoricain. - Mémoires de la Société géologique et minéralogique de Bretagne, 30: 1-268.

Le Menn, J. (1990): Les calices du genre Tiaracrinus (Crinoidea, Inadunata) dans l'Emsien d'Algérie et du Massif Armoricain. - Geobios 23(2): 161-167.

Meek, F. B., Worthen, A. H. (1866): Radiata, Echinodermata, Crinoidea. - Proceedings of the Academy of Natural Sciences of Philadelphia, 1866: 251-275.

Miller, S. A. (1892): Paleontology. - Annual Report, Indiana Department of the Geology and Natural Resources, 17(1891): 611-705.

Miller, S. A., Gurley, W. F. E. R. (1895): Description of new species of Palaeozoic Echinodermata. - Illinois State Museum of Natural History Bulletin, 5: 1-53, pl. 1-5.

Moore, R. C., Jeffords, R. M. (1968) : Classification and nomenclature of fossil crinoids based on studies of dissociated parts of their columns. - The University of Kansas Paleontological Contributions, 46(Echinodermata, Article 9): 1-86, pl. 1-28.

Moore, R. C., Laudon, L. R. (1943): Evolution and classification of Paleozoic crinoids. - Geological Society of America, Special Papers 46: 11-53, pl. 1-18.

Moore, R. C., Lane, G. N., Strimple, J., Sprinkle, J., Fay, R. O. (1978): Inadunata, Disparida. - In: Moore, R. C., Teichert, C. (eds), Treatise on Invertebrate Paleontology, Part T: Echindermata 2, volume 2, The Geological Society of America and The University of Kansas, Boulder and Lawrence, p. T520-T564.

Oehlert, D.-P. (1891): Description de deux crinoides nouveaux du Dévonien de la Manche. - Bulletin de Société Géologique de France, Sér. 3, 19: 834-853, pl. 18.

Phillips, J. (1836): Illustrations of the Geology of Yorkshire or a description of the Strata and organic remains. Pt 2. - John Murray, London, 253 pp., 25 pls.

Prokop, R. J. (1969): Ramacrinus multiformis gen. et sp. n. (Synbathocrinidae, Crinoidea) in the Devonian of Bohemia. - Věstník Ústředního ústavu geologického, 44(6): 375-377.

Prokop, R. J. (1970): Family Calceocrinidae Meek and Worthen, 1869 (Crinoidea) in the Silurian and Devonian of Bohemia. - Sborník geologických Věd, Paleontologie, 12: 79-134.
Prokop, R. J. (1973): Elicrinus n. gen. from the Lower Devonian of Bohemia (Crinoidea). - Věstník Ústředního ústavu geologického, 48(4): 221-223.

Prokop, R. (1982): Some new hexacrinitids (Crinoidea, Camerata) from the Lower Devonian of Bohemia. Věstník Ústředního ústavu geologického, 57(5): 277-283.

Prokop, R. J. (1987): The stratigraphical distribution of Devonian crinoids in the Barrandian area (Czechoslovakia). - Newsletters on Stratigraphy, 17(2): 101-107.

Prokop, R. J., Petr, V. (1989): Gemmacrinus perplexus n. gen., n.sp. (Crinoidea, ?Camerata or ?Inadunata) from Lower Devonian of Bohemia. - Sborník Národního muzea, řada B, 44(2): 127-135.

Prokop, R. J., Petr, V. (1991): New microcrinoids from the Třebotov Limestone of the Bohemian Lower Devonian $($ Dalejan $=$ Upper Emsian $)$. - Časopis pro mineralogii a geologii, 36(2-3): 131-136.

Prokop, R. J. (1992): Newly ascertained genera of crinoids in the Devonian of Bohemia (Barrandian area). - Journal of the National Museum (Prague), Natural History Series, 159(1990): 110.

Prokop, R. J., Petr, V. (1994): Timocrinus gen. n. (Crinoidea, Inadunata) from the Lower Devonian of Bohemia. Journal of the National Museum (Prague), Natural History Series, 162(for 1993)(1-4): 67-69.

Prokop, R. J. (2009): Holamptocrinus argutus gen. et sp. n. (Crinoidea, col.) from Lower Devonian, (Dalejan) of the Barrandian area (Czech Republic). - Journal of the National Museum (Prague), Natural History Series, 177(5): 49-51.

Prokop, R. J. (2013): Simakocrinus gen. nov. (Crinoidea, col.) from the Bohemian Early and Middle Devonian of the Barrandian Area (the Czech Republic). - Acta Musei Nationalis Pragae, Series B - Historia Naturalis, 69(1-2): $65-68$.

Schnur, J. (1849): Crinoiden. - In: Steininger, J. (ed.), Die Versteinerungen des Übergangsgebirges der Eifel. Jahresbericht über den Schul-Cursus 1848-1849 an dem Gymnasium zu Trier, published by the gymnasium, Trier, p. 21-22.

Schultze, L. (1867): Monographie der Echinodermen des Eifler Kalkes. - Denkschriften der Keiserlichen Akademie der Wissenschaften, mathematisch-naturwissenschaftliche Classe, 26: 113-230, pl. I-XIII. (Tiaracrinus p. 226-228, pl. XIII, fig. 8a, b.)

Shumard, B. F. (1868): A catalogue of the Palaeozoic fossils of North America. Part I. Paleozoic Echinodermata. Transaction of St. Luis Academy of Sciences, 2(1866): 334-407.

Springer, F. (1926): American Silurian Crinoids. Smithsonian Institution Publication, 2871: 1-239.

Stukalina, G. A. (1965): O taksonomicheskom znachenii stebley drevnikh morskikh lilii [On taxonomic significance of ancient crinoid stems]. - Trudy Vsesoyuznogo Nauchno-Issledovatelskogo Geologicheskogo Instituta, 115: 210-217. (in Russian)

Stukalina, G. A. (1975): Morskie lilii [Crinoids]. - In: Kharakteristika fauny pogranichnykh sloev silura i devona tsentral'nogo Kazakhstana [Fauna on the Silurian/ Devonian boundary from the Central Kazakhstan]. 
Materialy po Geologii Tsentral'nogo Kazakhstana, 12: 133-150. (in Russian)

Ubaghs, G. (1978): Skeletal morphology of Fossil Crinoids. - In: Moore, R. C., Teichert, C. (eds), Treatise on Invertebrate Paleontology, Part T: Echindermata 2, volume 1, The Geological Society of America and The University of Kansas, Boulder and Lawrence, p. T58T216.

Wachsmuth, C., Springer, F. (1880): Revision of the Palaeocrinoidea. Part I. - Proceedings of the Academia of the Natural Sciences of Philadelphia, 1880: 226-378.

Wachsmuth, C., Springer, F. (1885): Revision of the Palaeocrinoidea. Part III. Discussion of the classification and relations of the brachiate crinoids, and conclusion of the generic description. - Proceedings of the Academia of the Natural Sciences of Philadelphia, 37: 225-364.

Williams, H. S. (1883): On a Crinoid with Movable Spines. - Proceedings of the American Philosophical Society, 21: 81-88.

\section{Explanation of the Plate}

\section{PLATE 1}

Baficrinus vigilis gen. et sp. nov.

Early Devonian, Late Emsian (Dalejan), Daleje-Třebotov Formation, Třebotov Limestone. Abandoned "V rokli" quarry,

1a. NM-L42360, holotype, calyx in lateral view.

1b. dtto, calyx in oral view.

2a. NM-L42361, calyx in lateral view.

$2 b$. dtto, calyx in basal view.

2c. dtto, calyx in oral view.

3. Almost complete calyx, (specimen totaly disintegrated in the course of photography).

4. NM-L42364, radial plate, appears the outer surface with complicated network of epispires and radial wrinkles.

5. NM-L42365, dtto.

6. NM-L42363, dtto.

7. NM-L42362, radial plate, inner surface.

Note: Upper bar-scale at the Plate 1 is used for the complete specimen, the lower one for isolated radial plates. All specimens are deposited in the collections of the Palaeontological Department of the National Museum, Prague (abbrev. NM, catalogue L.)

Photos by V. Turek and Rudolf J. Prokop. 
PLATE 1

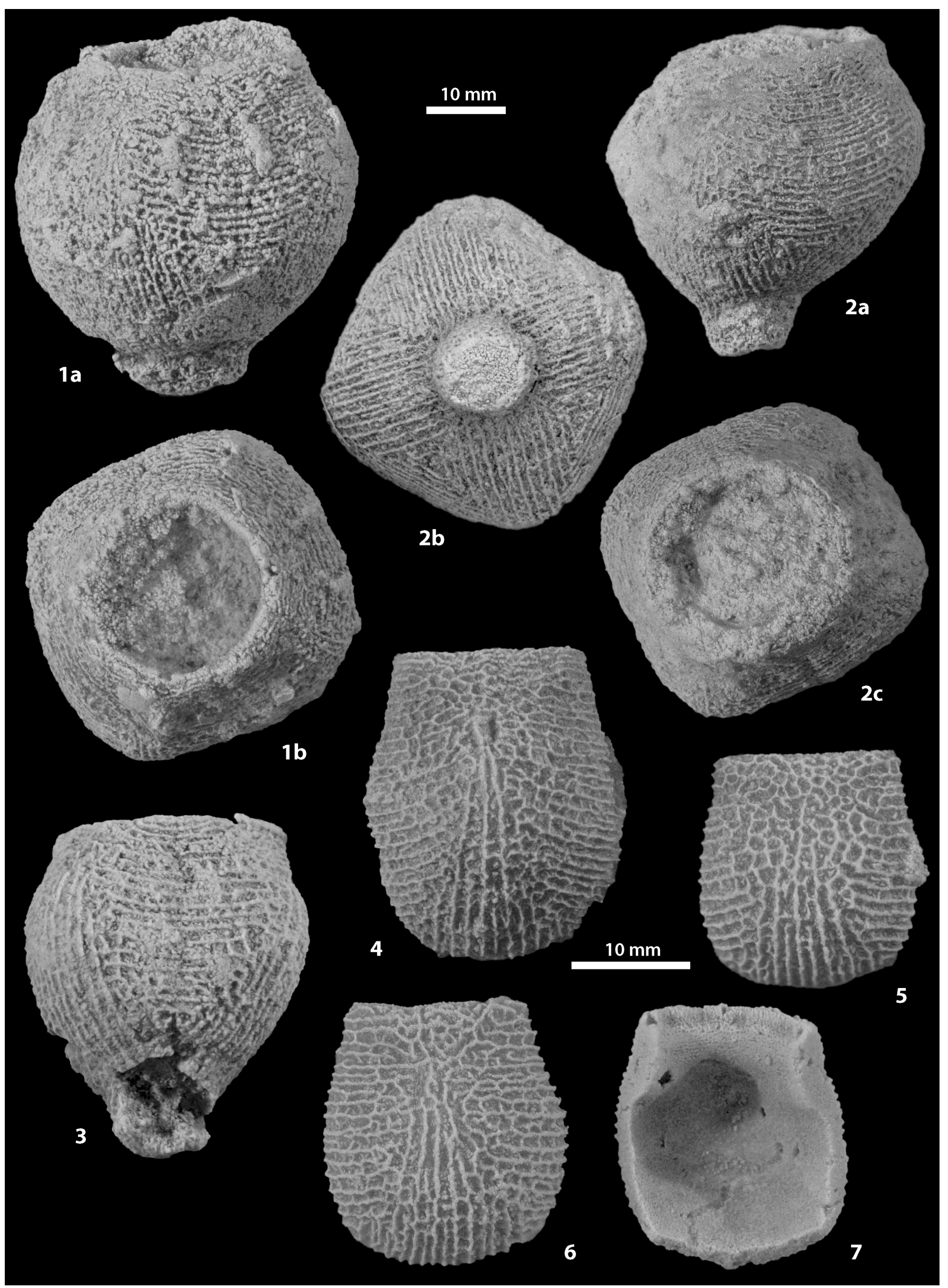

